\title{
Effect of More Doctors (Mais Médicos) Program on geographic distribution of primary care physicians
}

\author{
Efeito do Programa Mais Médicos \\ na distribuição geográfica dos médicos na atenção básica
}

Letícia Xander Russo (https://orcid.org/0000-0001-9592-8212) ${ }^{1}$

${ }^{1}$ Faculdade de

Administração, Ciências

Contábeis e Economia,

Universidade Federal da

Grande Dourados. Km

12, Caixa postal 364, Rod.

Dourados-Itahum. 79804-

970 Dourados MS Brasil.

leticiarusso@ufgd.edu.br

\begin{abstract}
This study assesses the effect of More Doctors Program (Programa Mais Médicos $P M M)$ on the equality in the distribution of primary care physicians (PCPs) in Brazil. Spatial data analysis, Lorenz curve and Gini coefficient were used to evaluate the geographic distribution of PCPs before and after the implementation of PMM (2012 and 2016). Data from 5,564 municipalities were used in the analyses. The results indicate that the distribution of PCPs has become more equal after PMM implementation. Between 2012 and 2016, overall Gini coefficient decreased by $11 \%$ from 0.255 to 0.227 . At the state level, a statistically significant trend towards a more equal distribution of PCPs was found in 21 out of 26 Brazilian states. However, there still remains a substantial difference in the level of equality in PCP distribution, especially across states, with Gini coefficient ranging from 0.093 to 0.341 in 2016.
\end{abstract}

Key words Physicians, Primary Health Care, Healthcare Disparities, Health Workforce
Resumo Este artigo avalia o efeito do Programa Mais Médicos (PMM) na distribuição de médicos na atenção básica no Brasil. As técnicas de análise de dados espaciais, curva de Lorenz e coeficiente de Gini foram empregadas para avaliar a distribuição geográfica dos médicos antes e após a implementação do PMM (2012 e 2016). Para tanto, foram utilizados dados secundários de $5.564 \mathrm{mu}$ nicípios. Os resultados indicaram que a distribuição de médicos se tornou mais igualitária após a implementação do PMM. Entre 2012 e 2016, o coeficiente geral de Gini diminuiu 11\%, passando de 0,255 para 0,227. No âmbito estadual, uma tendência estatisticamente significativa em direção a uma distribuição mais igualitária de médicos foi encontrada em 21 estados brasileiros. No entanto, ainda persiste uma diferença substancial na distribuição de médicos na atenção básica, especialmente entre os estados, com o coeficiente de Gini variando de 0,093 a 0,341 em 2016.

Palavras-chave Médicos, Atenção Básica à Saúde, Disparidades em Assistência à Saúde, Mão de Obra em Saúde 


\section{Introduction}

The geographic distribution of physicians has been a persistent issue worldwide ${ }^{1,2}$. Despite many countries facing the uneven distribution of these professionals, this is a matter of great concern for low- and middle-income countries, since the population already have limited access to health care ${ }^{3}$. In general, physicians tend to concentrate mainly on wealthier and larger urban areas in the country. The lack of physicians in rural, poor and peripheral regions implies in significant disparities in health outcomes between the populations ${ }^{2,4}$.

Over the past decades, different strategies have been adopted in order to attract and retain these professionals in underserved and high need areas ${ }^{3,5,6}$. In Brazil, despite great progress towards a more equitable access and utilization of health care $^{7-9}$, there still remains a marked unequal distribution of physicians across national territory. The unbalanced distribution of physicians is noticed even when compared the numbers between states. For example, Rio de Janeiro has 3.75 physicians per 1,000 population $(61,346$ physicians and $16,369,179$ population in 2014), while Maranhão, the poorest state in Brazil, has 0.79 physician per 1,000 population $(5,396$ physicians and $6,794,301$ population in 2014) $)^{10}$. Commonly, areas with lack of physicians are also areas with the largest population in need, intensifying the unequal access to health care ${ }^{11}$.

There are two major reasons why the unbalanced distribution of physicians across areas is a concern to policy makers and researchers. First, in countries with system founded on the principles of equality and social justice, there is an issue when part of population has limited access to health care. Second, an extensive literature indicates the link between physician availability, access to medical care and health status ${ }^{12,13}$. Clearly, these impacts are considerable for primary health care. In general, primary care physicians (PCPs) are more equally distributed than specialists, but maldistribution of PCPs also occurs in many countries ${ }^{14}$.

In recent years, Brazil has implemented new national policies to face the geographical maldistribution of health workforce, especially targeting primary care physicians. In 2013 was launched the More Doctors Program (Programa Mais Médicos - PMM). It was set up to reduce the shortage of physician in vulnerable areas and regional disparities in access to health ${ }^{15}$.

The positive impact of PMM on health indicators has been shown by an increasing number of studies ${ }^{16,17}$. However, there is a lack of evidence of the effect of the program towards a more equal distribution of physician at national level. Some studies have address this topic, but at the regional/local level or in a selected group of municipalities $^{18,19}$. The present study asses the effect of More Doctor Program on the geographic distribution of PCPs and its contribution to a more equal distribution of PCPs in Brazil.

\section{Brazilian strategies to deal with the maldistribution of physicians}

Since the military dictatorship period, Brazil has designed programs aimed at attracting and retaining health professionals in underserved areas. Although these programs range in size, scope and implementation path, the common purpose is to address the problem of lack of health professionals. Some of these programs had specific actions to recruit and attract physicians.

The Program for Internalization of the Unified Health System (Programa de Interiorização do Sistema Único de Saúde - PISUS) was created in 1993. The PISUS was a cooperation of the three branches of government targeting municipalities without health services. It had the goal of retaining at least one physician with residence in the selected municipality; besides the installation of a small healthcare center with basic equipment and healthcare team. Due to the lack of political support, the program was extinguished even before it was effectively implemented ${ }^{20}$.

The Program for Internalization of Health Work (Programa de Interiorização do Trabalho em Saúde - PITS) emerged in 2001. PITS used financial incentives and professional qualification to encourage physicians and nurses to move to selected municipalities. Initially, it was selected only municipalities with population of up 50 thousand inhabitants, no Family Health Program coverage, high infant mortality rate ( 80 per 1,000 live births), low indicator of medical consultation and participation in the Active Community or Alvorada Project. The Program selected 151 municipalities. In the second year of the program, some of the eligibility criteria of the municipalities were changed and 216 municipalities were selected. In additional to unfilled vacancies, the program registered the desistance of some professionals and municipalities in a few months. PITS ended in $2004^{20}$.

In 2010, the federal government adopted new strategies to address the problem of physicians' distribution. The Law No. 12,202/2010 decreed that physicians, who had their courses funded by 
the Fund for Financing Student in Higher Education (Fundo de Financiamento ao Estudante do Ensino Superior - FIES), could have their debts reduced if they worked on the Family Health Program located in areas with difficult retention of professionals ${ }^{21}$.

In 2011, another initiative was the Primary Care Professional Valorization Program (Programa de Valorização do Professional da Atenção Básica - PROVAB). It was created to encourage physicians, nurses and dental surgeons to move to underserved municipalities or areas with vulnerable population. A postgraduate course in family health and additional score of $10 \%$ on medical residency tests were offered to health professionals $^{22}$. Initially, the program attracted 380 physicians; in subsequent years it registered more than 3 thousand physicians. Even so, it did not meet all the shortage recorded by the municipalities ${ }^{23}$.

In January of 2013, the National Front of Brazilian Mayors (Frente Nacional de Prefeitos do Brasil - FNP), claiming support from the federal government, launched the campaign "Where is the Doctor" (Cadê o médico?). In October of 2013 was instituted the More Doctors Program (Programa Mais Médicos - PMM). It was created to reduce the shortage of physician in the priority SUS areas, minimize inequalities and strengthen the provision of primary care ${ }^{15}$. The actions of the program follow 3 bases: emergency supply of physicians; expansion and improvement of the infrastructure of primary healthcare centers and; creation of new medical schools and qualification of medical workforce ${ }^{23}$. PMM and PROVAB coexisted in parallel until the beginning of 2015, when PROVAB became part of the PMM.

PMM followed a combined set of criteria to classify the priorities regions, including: areas with high percentage of the population living in extreme poverty; low human development index; municipalities located in semi-arid and Amazon region; areas with indigenous and Maroon population and; areas with difficult to recruit and retain workforce ${ }^{15}$. After two years, the program recorded the participation of 18,240 physicians (Brazilians and foreigners) in 4,058 municipalities and 34 indigenous health districts ${ }^{24}$.

\section{Methods}

This study investigates the effects of PMM on geographic distribution of primary care physicians and uses two years for comparison purposes, 2012 and 2016 (before and after PMM im- plementation). The analysis includes data from 5,564 municipalities.

\section{Data}

Primary care physician density is defined as the total number of PCPs per 10,000 population in each municipality. The PCP data source is the Information Department of Brazil's Unified Health System (DATASUS) from the Brazilian Ministry of Health. The TabWin 32 (Tab for Windows) program was used for collect the data. Primary care physicians include physicians from the Family Health Strategy (FHS) and Primary Health Teams (PHT). It was included only PCPs who work in healthcare centers designed to provide primary health care to the population (Centro de Saúde/Unidade Básica de Saúde, Posto de Saúde and Centro de Apoio a Saúde da Família - CASF). Physicians working in hospitals are not included. In Brazil, it is known that physicians can work different number of hours and/ or in more than one municipality. So, for a more accurate number of the provision of this service and avoid an overestimation, the total number of PCPs is calculated dividing the total hours worked weekly in the municipality by 40 .

\section{Analysis}

The study uses different approaches to analyse the inequality in the distribution of PCPs. First, it was employed spatial data analysis, where the geographic distribution of PCPs and patterns of spatial association (clusters) were displayed. The maps of geographic distribution provide some indicators regarding the inequality that exist across Brazilian municipalities. The cluster maps detect patterns of spatial dependence between neighbouring municipalities. Spatial dependence (or spatial autocorrelation) can be interpreted a systematic pattern in the values recorded in geographic space ${ }^{25,26}$. To identify local patterns of spatial association, it was calculated the Local Indicator of Spatial Association (LISA). In formal terms, LISA statistic can be expressed as follows ${ }^{27}$ :

$$
\begin{aligned}
& I_{i, t}=\frac{x_{i, t}-\mu_{t}}{m_{0}} \sum_{j} w_{i, j}\left(x_{j, t}-\mu_{t}\right) \quad \text { with } \\
& \mathrm{m}_{0}=\sum_{i}\left(x_{i, t}-\mu_{t}\right)^{2} / n
\end{aligned}
$$

Where $x_{i, t}$ represents the observation in municipality $i$ and year $t ; \mu_{t}$ corresponds the mean of the observation across municipalities in year 
$t$ and the summation over $j$ includes only neighbouring values of $j$.

Then, the Lorenz curves and Gini coefficient were used to evaluate the level of inequality in the distribution of PCPs. These measures have been widely employed to analyse the distribution of physicians $\mathrm{s}^{28-30}$. Lorenz curve illustrates the entire distribution and allows to compare how the structure of inequality change over time. Lorenz Curves is displayed with cumulative population proportion on the horizontal axis and cumulative proportion of PCPs on vertical axis. The diagonal line represents the complete equity. This study follows the formal definition of Lorenz curve given by Jann ${ }^{31}$.

The Gini coefficient is derived from the Lorenz curve and it is calculated by the ratio of the area between the Lorenz curve and the diagonal line, and the whole area bellow the diagonal line. The closer the Lorenz curve is the equity line (diagonal), the smaller is Gini coefficient. It is also possible to compare two Lorenz curves. If the curves do not cross, the Lorenz curve closer to the diagonal line has the lower Gini coefficient. Gini coefficient ranges from 0 (perfect equality) to 1 (perfect inequality) 32 .

The following equation was estimated to calculate the time trend in the Gini coefficient:

$$
G_{i}=\beta_{0}+\beta_{1} \text { Year }+\varepsilon_{i}
$$

Where $G_{i}$ is the Gini coefficient for the unit of analysis $i$ and $\varepsilon_{i}$ denotes the error term. The equation (1) was estimated for Brazil and each state (26 states) and region (5 regions).

\section{Results}

The number of PCPs has increased considerably after the implementation of More Doctor Program. The average number of PCPs in Brazilian municipalities increased from 3.45 per 10,000 population in 2012 to 3.93 per 10,000 population in 2016. Figure 1 shows the kernel density plots of PCPs before and after PMM. There was an increase of PCPs in municipalities with shortage of these professionals. In 2012, there were $43 \mathrm{mu}$ nicipalities without PCP and 952 municipalities with less than 2 PCPs per 10,000 population. In 2016, there was an expressive reduction of municipalities with a low number of PCPs. It was recorded 13 municipalities without PCP (70\% decrease) and 500 municipalities with less than 2 PCPs per 10,000 population (47\% decrease).
Brazilian municipalities have an expressive uneven distribution of physicians. The municipal number of PCPs ranged from 0 to 16.2 PCPs per 10,000 population in 2012 and from 0 to 16.1 PCPs per 10,000 population in 2016 . The municipalities with shortage of physicians are located in all Brazilian regions. However, there is a massive concentration of these municipalities in the North, the poorest region of the country. Figure 2 displays the spatial distribution of the municipalities below and above the average number of PCPs. North region is clearly the area with the lowest density of PCPs and largest spatial concentration in both years (Maps (A) and (B)). Map (C) shows the municipalities that increased the number of PCPs after PMM implementation. In general, although the same municipalities remain below average in both years, it is noted that they received more physicians in 2016.

Figure 3 shows the cluster analysis of PCPs per 10,000 population in Brazilian municipalities in (A) 2012 (B) and 2016. The majority of the identified clusters are formed by municipalities with low number of PCPs per 10,000 population surrounded by municipalities with low number of PCPs, representing $58.4 \%$ of the total clusters in 2012 and $57.8 \%$ in 2016. Municipalities with high number of PCPs per 10,000 population surrounded by municipalities with high PCPs represented $18 \%$ of the total clusters in 2012 and $20.2 \%$ in 2016 . The total number of municipalities identified as clusters was 1,086 in 2012 and 1,143 in 2016. Even after a significant increase in the number of PCPs, the univariate analyses show a large low-low cluster in North region in 2016. The number of low-low clusters demonstrates that the spatial concentration occurs mainly due to the lack of physicians.

Lorenz curves both before and after PMM are represented in Figure 4. The curve corresponding to the PCP density in 2016 is closer to the diagonal, compared to the curve representing the PCP density in 2012. It shows that the distribution of PCPs was better balanced in 2016 than was the distribution of physicians in 2012.

Trends in the Gini coefficient for the distribution of PCPs between 2012 and 2016 are shown in Table 1. The Gini coefficient was 0.255 in 2012 and 0.227 in 2016, which corresponds to a decrease of $11 \%$. The Gini coefficient showed a statistically significant trend from 2012 to 2016 $(\mathrm{p}<0.01)$.

The distribution of PCPs has become more equal after PMM implementation in 4 (North, Southeast, Northeast, South) out of 5 regions. 


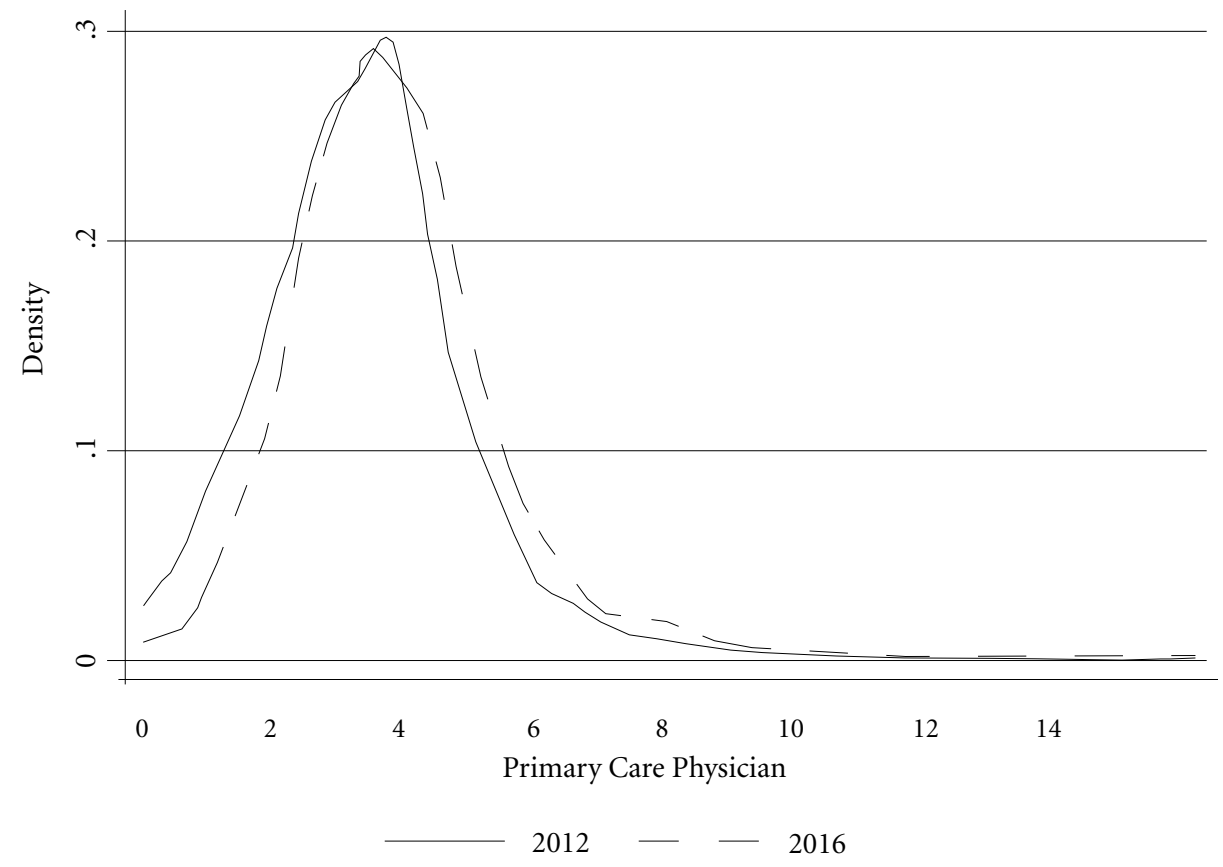

Figure 1. Kernel density plots of primary care physicians in Brazilian municipalities in 2012 and $2016^{a}$.

${ }^{a}$ Number of PCPs per 10,000 population.
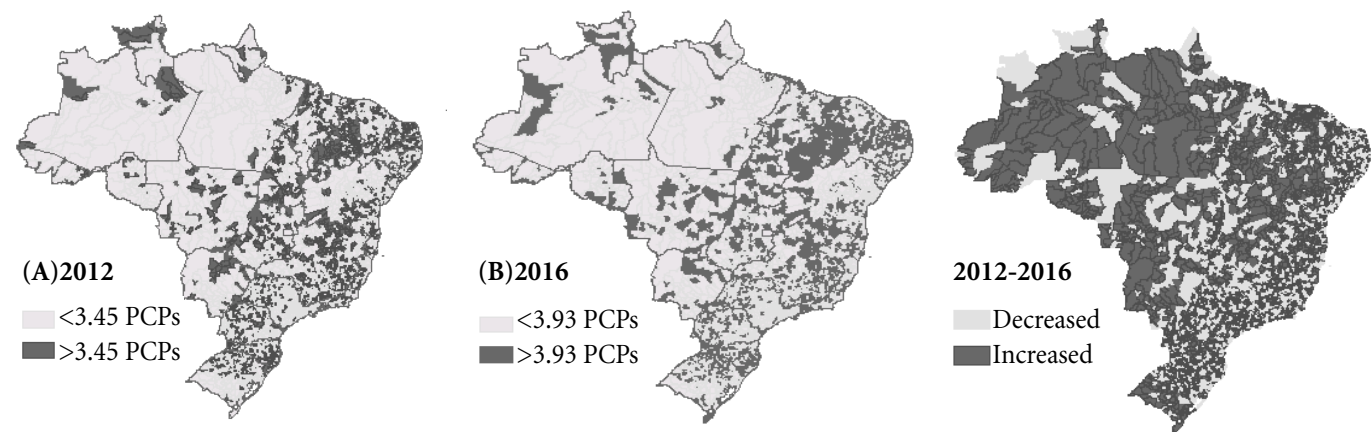

Figure 2. Geographical distribution and changes in the number of primary care physicians in Brazilian municipalities, 2012 and 2016.

${ }^{a}$ Number of PCPs per 10,000 population.

In North, Gini coefficient reduced by $23 \%$ from 0.300 in 2012 to 0.230 in 2016 . North is the region where was identified a large low-low cluster, as showed in Figure 3.
It was identified a statistically significant trend towards a more equal distribution of PCPs in 21 out of 26 states, with Gini coefficient change ranging from $-37 \%$ to $-6 \%$. The distribution of 
(A) 2012

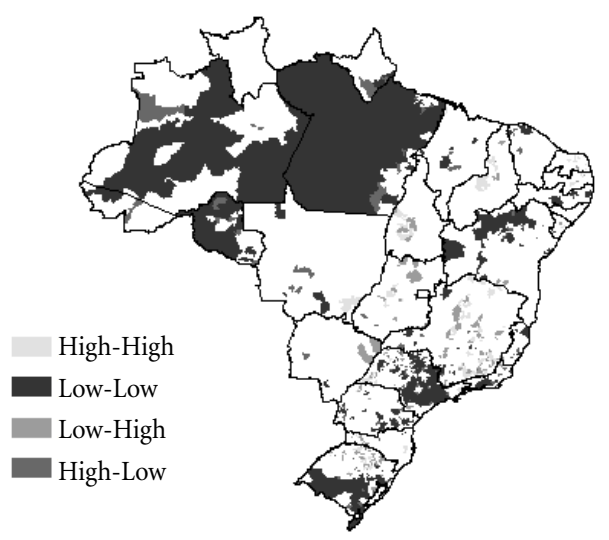

(B)2016

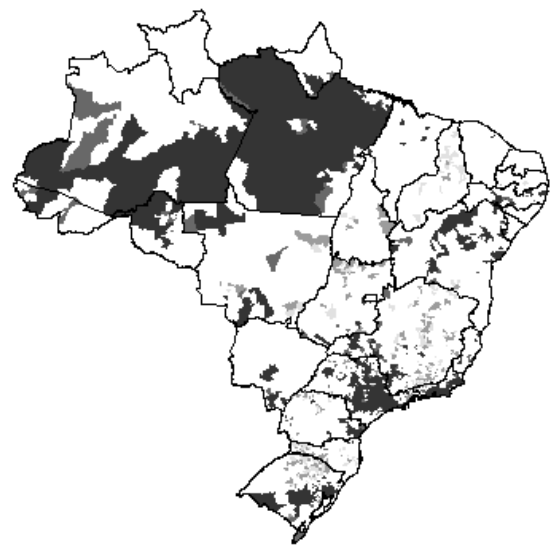

Figure 3. Cluster maps of primary care physicians distribution, 2012 and $2016^{\mathrm{a}}$.

${ }^{a}$ Number of PCPs per 10,000 population. The chosen matrix was the queen. Moran's I value was 0.1934 in 2012 and 0.2058 in 2016. Moran's I value was statistically significant at $1 \%$ in both years.

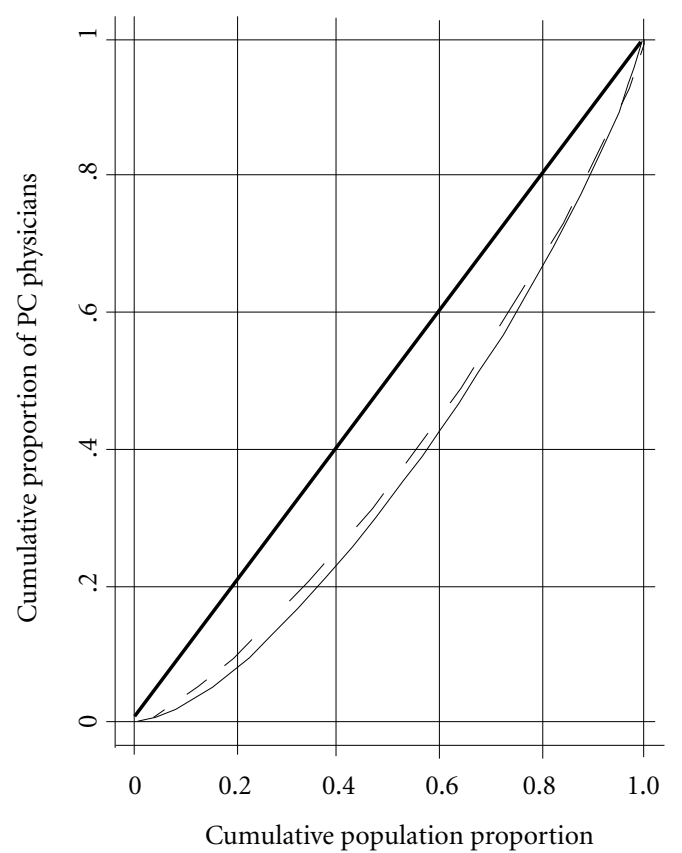

$2012--2016$

Figure 4. Lorenz curves of primary care physicians in 2012 and $2016^{\mathrm{a}}$.

${ }^{a}$ Number of PCPs per 10,000 population.
PCPs has become more unequal in 3 states, but only Goiás exhibited a statistically significant trend toward increasing inequality $(\mathrm{p}<0.05)$.

Despite substantial improvements in PCP distribution, there is still an expressive difference in the level of equality in physician distribution in 2016, especially across states. São Paulo is the state in which PCPs are most unequally distributed (0.341), while Piauí is the most equal state (0.0093).

\section{Discussion}

This paper addresses the problem of distribution of physicians in the Brazilian municipalities. Since the 70's, the government has adopted strategies to recruit and retain physicians in underserved areas and regions with shortage of health professionals. In general, these strategies have been targeted towards primary care and focused to ensure the equitable access of health service around the country ${ }^{20}$.

In 2013, More Doctors Program was instituted to provide physicians to remote and deprived areas. This study presented an overview of the effect of More Doctor Program on the distribution of PCPs and assessed its contribution to a more equal distribution of PCPs in Brazil. Between 2012 and 2016, overall Gini coefficient decreased 
Table 1. Trends in the Gini coefficient for the distribution of primary care physicians per 10,000 population in Brazil between 2012 and 2016 .

\begin{tabular}{|c|c|c|c|c|c|c|c|c|}
\hline Region/State ${ }^{\mathrm{b}}$ & 2012 & 2013 & 2014 & 2015 & 2016 & Coefficient & $\begin{array}{c}\text { p-value } \\
\text { (robust S.E.) }\end{array}$ & $\begin{array}{c}\text { \% change } \\
(2012-2016)\end{array}$ \\
\hline Brazil & 0.255 & 0.250 & 0.238 & 0.231 & 0.227 & -0.007 & $<0.01$ & $-11 \%$ \\
\hline North & 0.300 & 0.284 & 0.254 & 0.235 & 0.230 & -0.019 & $<0.01$ & $-23 \%$ \\
\hline RO & 0.304 & 0.250 & 0.227 & 0.199 & 0.191 & -0.028 & $<0.05$ & $-37 \%$ \\
\hline $\mathrm{AC}$ & 0.200 & 0.208 & 0.190 & 0.125 & 0.139 & -0.020 & $<0.05$ & $-30 \%$ \\
\hline $\mathrm{RR}$ & 0.178 & 0.190 & 0.192 & 0.139 & 0.125 & -0.016 & $<0.10$ & $-30 \%$ \\
\hline $\mathrm{AM}$ & 0.259 & 0.252 & 0.190 & 0.185 & 0.189 & -0.021 & $<0.05$ & $-27 \%$ \\
\hline PA & 0.347 & 0.336 & 0.290 & 0.272 & 0.262 & -0.023 & $<0.01$ & $-24 \%$ \\
\hline TO & 0.200 & 0.191 & 0.168 & 0.162 & 0.170 & -0.009 & $<0.10$ & $-15 \%$ \\
\hline $\mathrm{AP}$ & 0.155 & 0.155 & 0.178 & 0.176 & 0.140 & -0.001 & 0.899 & $-9 \%$ \\
\hline Southeast & 0.315 & 0.307 & 0.292 & 0.280 & 0.271 & -0.011 & $<0.01$ & $-14 \%$ \\
\hline ES & 0.239 & 0.222 & 0.191 & 0.181 & 0.182 & -0.016 & $<0.05$ & $-24 \%$ \\
\hline SP & 0.412 & 0.404 & 0.374 & 0.348 & 0.341 & -0.020 & $<0.01$ & $-17 \%$ \\
\hline RJ & 0.277 & 0.273 & 0.237 & 0.236 & 0.237 & -0.012 & $<0.05$ & $-14 \%$ \\
\hline MG & 0.239 & 0.230 & 0.225 & 0.223 & 0.213 & -0.006 & $<0.01$ & $-11 \%$ \\
\hline Northeast & 0.178 & 0.175 & 0.160 & 0.157 & 0.155 & -0.006 & $<0.01$ & $-13 \%$ \\
\hline SE & 0.200 & 0.211 & 0.160 & 0.137 & 0.142 & -0.019 & $<0.05$ & $-29 \%$ \\
\hline $\mathrm{CE}$ & 0.191 & 0.168 & 0.139 & 0.141 & 0.137 & -0.014 & $<0.05$ & $-28 \%$ \\
\hline PE & 0.183 & 0.172 & 0.159 & 0.151 & 0.148 & -0.009 & $<0.01$ & $-19 \%$ \\
\hline BA & 0.203 & 0.192 & 0.174 & 0.169 & 0.165 & -0.010 & $<0.01$ & $-19 \%$ \\
\hline $\mathrm{AL}$ & 0.152 & 0.158 & 0.145 & 0.138 & 0.128 & -0.007 & $<0.05$ & $-16 \%$ \\
\hline PI & 0.109 & 0.117 & 0.097 & 0.094 & 0.093 & -0.006 & $<0.05$ & $-15 \%$ \\
\hline MA & 0.168 & 0.170 & 0.147 & 0.141 & 0.144 & -0.008 & $<0.05$ & $-14 \%$ \\
\hline $\mathrm{RN}$ & 0.170 & 0.164 & 0.152 & 0.162 & 0.156 & -0.003 & $<0.10$ & $-8 \%$ \\
\hline $\mathrm{PB}$ & 0.121 & 0.114 & 0.120 & 0.123 & 0.122 & 0.001 & 0.399 & $1 \%$ \\
\hline South & 0.264 & 0.261 & 0.255 & 0.246 & 0.245 & -0.005 & $<0.01$ & $-7 \%$ \\
\hline RS & 0.318 & 0.312 & 0.296 & 0.284 & 0.284 & -0.010 & $<0.01$ & $-11 \%$ \\
\hline PR & 0.232 & 0.234 & 0.229 & 0.217 & 0.217 & -0.005 & $<0.05$ & $-6 \%$ \\
\hline SC & 0.204 & 0.200 & 0.211 & 0.211 & 0.204 & 0.001 & 0.437 & $0 \%$ \\
\hline Midwest & 0.223 & 0.224 & 0.233 & 0.237 & 0.234 & 0.004 & $<0.05$ & $5 \%$ \\
\hline MS & 0.200 & 0.182 & 0.178 & 0.154 & 0.160 & -0.011 & $<0.05$ & $-20 \%$ \\
\hline GO & 0.228 & 0.226 & 0.245 & 0.249 & 0.247 & 0.006 & $<0.05$ & $9 \%$ \\
\hline MT & 0.214 & 0.231 & 0.227 & 0.241 & 0.229 & 0.004 & 0.24 & $7 \%$ \\
\hline
\end{tabular}

by $11 \%$ from 0.255 to 0.227 . At the state level, a statistically significant trend towards a more equal distribution of PCPs was found in 21 Brazilian states.

It was identified only one study that had applied the Gini coefficient to evaluate inequality trends in the distribution of health workers in Brazil. Sousa et al. ${ }^{33}$ used data of Brazilian Minimum Comparable Areas (MCA) for 1991, 2000 and 2005. The authors found that the Gini for physicians was 0.60 in 1991 and 0.58 in 2000 and 2005. These coefficients are larger than the found in this study. However, they measured the inequalities in the distribution of all physicians, including specialists, which it is much more concentrated than primary care physicians. The ratio of specialists to generalists in Brazil is 1.67, with a significant difference between the regions, for example, the ratio of specialists to generalists is 2.27 in South and 1.06 in North ${ }^{34}$.

The results are consistent with previous studies, which show that the recent increased in the 
level of PCPs has contributed towards a more equal distribution of PCPs in Brazil. The More Doctor Program has been succeeded in providing physicians to vulnerable and deprived areas ${ }^{18,35,36}$, including semi-arid zone ${ }^{37}$, indigenous areas ${ }^{19}$, Maroon communities ${ }^{38}$ and rural Amazon ${ }^{39}$.

After the implementation of PMM, the number of municipalities without PCP decreased by $70 \%$ and the number of municipalities with less than 2 PCPs per 10,000 population decreased by $47 \%$. Girardi et al..$^{40}$ identified that the number of municipalities with shortage of physicians decreased by $35 \%$ after implementation of the program, 1,200 municipalities in 2013 and 777 municipalities in 2015. They used the Primary Healthcare Physicians Shortage Index, which takes into account, besides the number of physicians, the infant mortality rate, the access to health service (distance) and percentage of poor households.

The cluster analysis evidence the uneven distribution of these professionals faced, especially, in the North region. This is the region with highest proportion of municipalities with scarcity of physicians ${ }^{40}$. The large low-low cluster may indicate that these municipalities and its neighbours follow similar policies, and may also have closely resembling regional characteristics. After the implementation of PMM, North was the region with largest drop in Gini coefficient. This expressive reduction of scarcity of physician in the North has been reported in the literature ${ }^{36,40}$.

Despite the lowest Gini coefficient, Northeast is the region that received the largest number of PMM physicians ${ }^{41}$. This is explained by poor social and health indicators in the region, also criteria considered by the program ${ }^{19}$. In general, the limited access to healthcare is often associated with poor socioeconomic indicators, such as lower income and higher levels of social vulnerabilities ${ }^{42}$. This combination of limited access to health care and poor socioeconomic indicators contributes to aggravate the health status of the population.

In conclusion, findings in this study evidence that the implementation of PMM has contributed to reduce inequalities in the distribution of PCPs in Brazil. This experience shows the relevance of policies oriented at promoting a more equal distribution of physicians, especially in a context with notable disparities in access to healthcare. However, although the recent increase in the number of PCPs has led to systemic changes, there is still substantial difference in the level of equality in PCP distribution across geographic regions. 


\section{References}

1. Kroezen M, Dussault G, Craveiro I, Dieleman M, Jansen C, Buchan J, Barriball L, Rafferty AM, Bremner J, Sermeus W. Recruitment and retention of health professionals across Europe: A literature review and multiple case study research. Health Policy 2015; 119(12):1517-1528.

2. Dussault G, Franceschini MC. Not enough there, too many here: understanding geographical imbalances in the distribution of the health workforce. Human Resources Health 2006; 27(4):12.

3. Araújo E, Maeda A. How to recruit and retain health workers in rural and remote areas in developing countries: A Guidance Note. Washington: HNP; 2013.

4. Anand S, Barnighausen T. Human resources and health outcomes: cross-country econometric study. Lancet 2004; 364(9445):1603-1609.

5. Wilson NW, Couper ID, Vries ED, Reid S, Fish T, Marais $\mathrm{BJ}$. A critical review of interventions to redress the inequitable distribution of healthcare professionals to rural and remote areas. Rural Remote Health 2009; 9(2):1060.

6. Dolea C, Stormont L, Braichet J-M. Evaluated strategies to increase attraction and retention of health workers in remote and rural areas. Bull WHO 2010; 88(5):379-385.

7. Mullachery P, Silver D, Macinko J. Changes in health care inequity in Brazil between 2008 and 2013. International J Equity Health 2016; 15(1):140.

8. Castro MC, Massuda A, Almeida G, Menezes-Filho NA, Andrade MV, Noronha KVMdS, Rocha R, Macinko J, Hone T, Tasca R, Giovanella L, Malik AM, Werneck H, Fachini LA, Atun R. Brazil's unified health system: the first 30 years and prospects for the future. Lancet 2019; 394(10195):345-356.

9. Paim J, Travassos C, Almeida C, Bahia L, Macinko J. The Brazilian health system: history, advances, and challenges. Lancet 2011; 377(9779):1778-1797.

10. Scheffer M, Viecili PR, Cassenote A. Demografia médica no brasil 2015. São Paulo: Conselho Regional de Medicina do Estado de São Paulo, Conselho Federal de Medicina; 2015.

11. Campos FE, Machado MH, Girardi SN. The retention of health professionals in high need areas. Divulgação Saúde Debate 2009; 44(11):11.

12. Pitblado JR, Pong RW. Geographic Distribution of Physicians In Canada: Reproduced with permission of the Minister of Public Works and Government Services. Sudbury: Centre for Rural and Northern Health Research Laurentian University; 2000.

13. Basu S, Berkowitz SA, Phillips RL, Bitton A, Landon BE, Phillips RS. Association of Primary Care Physician Supply With Population Mortality in the United States, 2005-2015. JAMA 2019; 179(4):506-514.

14. Matsumoto M, Inoue K, Farmer J, Inada H, Kajii E. Geographic distribution of primary care physicians in Japan and Britain. Health Place 2010; 16(1):164-166.

15. Brasil. Lei $\mathrm{n}^{\circ} 12.871$, de 22 de outubro de 2013. Institui o Programa Mais Médicos, altera as Leis no 8.745, de 9 de dezembro de 1993, e no 6.932, de 7 de julho de 1981, e dá outras providências. Diário Ofical da União 2013; 23 out.
16. Santos JRR, Santos HG, Dias CMM, Chiavegatto Filho ADP. Assessing the impact of a doctor in remote areas of Brazil. Int J Public Health 2020; 65(3):267-272.

17. Fontes LFC, Conceição OC, Jacinto PA. Evaluating the impact of physicians' provision on primary healthcare: Evidence from Brazil's More Doctors Program. $\mathrm{He}$ alth Economics 2018; 27(8):1284-1299.

18. Santos LMP, Oliveira A, Trindade JS, Barreto IC, Palmeira PA, Comes Y, Santos FO, Santos W, Oliveira JPA, Pessoa VM, Shimizu HE. Implementation research: towards universal health coverage with more doctors in Brazil. Bull WHO 2017; 95(2):103-112.

19. Nogueira PTA, Bezerra AFB, Leite AFB, Carvalho IMS, Gonçalves RF, Brito-Silva KS. Characteristics of the distribution of doctors in the Mais Medicos (More Doctors) Program in the states of Brazil's Northeast. Cien Saude Colet 2016; 21(9):2889-2898.

20. Maciel Filho R, Branco MAF. Rumo ao Interior: médicos, saúde da família e mercado de trabalho. Rio de Janeiro: Editora Fiocruz; 2008.

21. Brasil. Lei no 12.202 , de 14 janeiro de 2010. Altera a Lei no 10.260 , de 12 de julho de 2001, que dispõe sobre o Fundo de Financiamento ao Estudante do Ensino Superior - FIES (permite abatimento de saldo devedor do FIES aos profissionais do magistério público e médicos dos programas de saúde da família; utilização de débitos com o INSS como crédito do FIES pelas instituições de ensino; e dá outras providências). Diário Ofical da União; 2010.

22. Brasil. Portaria Interministerial $\mathrm{n}^{\circ} 2.087$, de $1^{\circ} \mathrm{de}$ setembro de 2011. Institui o Programa de Valorização do Profissional da Atenção Básica. Diário Oficial da União; 2011.

23. Brasil. Ministério da Saúde (MS). Secretaria de Gestão do Trabalho e da Educação na Saúde. Programa Mais Médicos - dois anos: mais saúde para os brasileiros. Brasília: MS; 2015.

24. Brasil. Mais Médicos: Resultado para o País [Internet]. 2016 [acessado 2019 Jun 10]. Disponível em: http:// maismedicos.gov.br/resultados-para-o-pais.

25. Anselin L. The Moran scatterplot as an ESDA tool to assess local instability in spatial association. In: Fischer MM, Scholten HJ, Unwin D, editores. Spatial Analytical Perspectives on GIS. London: Taylor \& Francis; 1996.

26. Anselin L. Spatial Econometrics: Methods and Models. Netherlands: Springer; 1998.

27. Ertur C, Gallo JL. An Exploratory Spatial Data Analysis of European Regional Disparities, 1980-1995. In: Fingleton B, editor. European Regional Growth. Berlin: Springer Verlag; 2003.

28. Erdenee O, Paramita SA, Yamazaki C, Koyama H. Distribution of health care resources in Mongolia using the Gini coefficient. Hum Resour Health 2017; 15(1):56.

29. Ünal E. How the government intervention affects the distribution of physicians in Turkey between 1965 and 2000. Int J Equity Health 2015; 14:1. 
30. Kanchanachitra C, Lindelow M, Johnston T, Hanvoravongchai P, Lorenzo FM, Huong NL, Wilopo SA, dela Rosa JF. Human resources for health in southeast Asia: shortages, distributional challenges, and international trade in health services. Lancet 2011; 377(9767):769781.

31. Jann B. Estimating Lorenz and concentration curves. Stata J 2016; 16(4):837-866.

32. Atkinson $\mathrm{AB}$, Bourguignon $\mathrm{F}$. Handbook of income distribution. Amsterdam: North Holland; 2015.

33. Sousa A, Poz MRD, Carvalho CL. Monitoring inequalities in the health workforce: the case study of Brazil 1991-2005. PloS One 2012; 7(3):e33399.

34. Scheffer M, Cassenote A, Guilloux AGA, Biancarelli A, Miotto BA, Mainardi GM. Demografia Médica no Brasil 2018. São Paulo: FMUSP, CFM, Cremesp; 2018.

35. Silva BP, Stockmann D, Lúcio DS, Henna E, Rocha MCP, Junqueira FM. Expanding health access in the more vulnerable region in the state of Sao Paulo, Brazil: is this a reflection of the Mais Medicos (More Doctors) Program? Cien Saude Colet 2016; 21(9):28992906.

36. Pinto HA, Oliveira FP, Santana JSS, Santos FOS, Araujo SQ. The Brazilian More Doctors Program: evaluating the implementation of the "Provision" axis from 2013 to 2015. Interface (Botucatu) 2017; 21(Supl. 1):1087-1101.

37. Mattos E, Mazetto D. Assessing the impact of more doctors' program on healthcare indicators in Brazil. World Development 2019; 123:104617.

38. Pereira LL, Santos LMP, Santos W, Oliveira A, Rattner D. Mais Médicos program: provision of medical doctors in rural, remote and socially vulnerable areas of Brazil, 2013-2014. Rural Remote Health 2016; 16(1):3616.
39. Pereira LL, Pacheco L. The challenges faced by the More Doctors Program in providing and ensuring comprehensive health care in rural areas in the Amazon region, Brazil. Interface (Botucatu) 2017; 21 (Supl. 1):1181-1192.

40. Girardi SN, Stralen ACS, Cella JN, Maas LWD, Carvalho CL, Faria EO. Impact of the Mais Medicos (More Doctors) Program in reducing physician shortage in Brazilian Primary Healthcare. Cien Saude Colet 2016; 21(9):2675-2684.

41. Miranda GMD, Mendes ACG, Silva ALA, Santos Neto PM. Family health team expansion and the More Doctors program in brazilian municipalities. Trab Educ Saúde 2017; 15(1):131-145.

42. Oliveira APC, Gabriel M, Poz MRD, Dussault G. Challenges for ensuring availability and accessibility toin health care services under Brazil's Unified Health System (SUS). Cien Saude Colet 2017; 22(4):1165-1180.

Article submitted 21/07/2020

Approved 28/01/2021

Final version submitted 30/01/2021

Chief Editors: Romeu Gomes, Antônio Augusto Moura da Silva 